\title{
Research on Venture Capital Investment Exit in China
}

\author{
Wenjie Fan \\ School of Economics, Jinan University, Guangzhou, China \\ Email: gabrielfan@163.com
}

How to cite this paper: Fan, W.J. (2019) Research on Venture Capital Investment Exit in China. Modern Economy, 10, 464-473.

https://doi.org/10.4236/me.2019.102031

Received: January 18, 2019

Accepted: February 15, 2019

Published: February 18, 2019

Copyright (C 2019 by author(s) and Scientific Research Publishing Inc. This work is licensed under the Creative Commons Attribution International License (CC BY 4.0).

http://creativecommons.org/licenses/by/4.0/

\begin{abstract}
With the continuous improvement of China's capital market, China's venture capital investment has also grown, regardless of the number of institutions or the size of funds managed. The exit from venture capital is the last and most important part. This paper sorts out the way and performance of China's venture capital investment projects by sorting out the historical data. It is found that although the number of venture capital investment in China continues to grow, it is still close half of the projects withdrawn with lost. Although IPO exits have the highest revenue, it does not have a higher proportion than repurchase and mergers and acquisitions because of its long time and difficulty. In the case of relatively high repurchase and mergers and acquisitions, repurchase is a loss in most cases.
\end{abstract}

\section{Keywords}

Venture Capital, Ways of Exit, Performance of Exit

\section{Introduction}

Venture Capital is known as venture capital investment. According to the history of China's venture capital development, there are about three main stages of development in China's venture capital: The first stage is from the 1990s to 2000, investing mainly equity Investment in Domestic Growth Enterprises; The second stage is from the beginning of this century to 2005; most of venture capital institutions have closed down except that a small number of them strive. The main factor is the impact of the US Internet stock bubble, but it also shows that the local venture capital institutions are still immature; The third stage is from 2005 to the present. With the completion of the share-trading reform of the securities market, the successful launch of the GEM and the introduction of relevant policies and regulations that promote the listing of mature enterprises in 
the domestic securities market, China's venture capital industry ushered in the third peak period of development.

In 2016, the number of institutions in China's venture capital industry reached 2045, an increase of 270 from 2015, an increase of 15.2\%. Among them, there were 1421 venture capital investment funds, an increase of 270 from 2015, an increase of $8.4 \%$; and 624 venture capital investment management institutions, an increase of 160 from 2015. The increase was 34.5\%; the disclosure of 152 new funds raised in the same year; the new raised fund management capital of 101.61 billion yuan. Compared with foreign countries, China's venture capital investment has developed rapidly in recent years. In 2016, the number of venture capital institutions and management capital was only one thousand US. In 2016, the number of venture capital institutions in the United States reached 2460 (including 1562 venture capital funds and 8.98 management institutions), with a total management capital of 333 billion US dollars (2).

The venture capital step is divided into raising funds-screening projects-formal signing of agreements-investment-exiting, and venture capital exit is the final step in venture capital activities, but it is also the most important link. First, a sound venture capital exit mechanism can maintain the stability and continuity of venture capital. Second, the exit mechanism is the key to ensuring continuous access to venture capital. This paper will study the exit performance of Chinese venture capital enterprises from the aspects of exit mode and performance.

\section{Literature}

Ren Heda [1] pointed that the important reason for the slow development of China's venture capital industry is the lack of effective exit mechanism. Zhengke and Zheng Xiaoqi [2] discuss the main practical ways that China's venture capital exit can be adopted through the comparative analysis of the exit channels of venture capital. According to Brau [3], the premium level of venture capital projects when they exit through IPO is $22 \%$ higher than when they exit through mergers and acquisitions. Nahata [4] pointed out that to make investors convinced of attractive returns and then to raise additional capital, successful exit is the key. The choice of exit means is determined by both factors of the enterprise and venture capital. A well-performing venture company can not only bring a more successful exit (IPO or acquisition), but it is also possible that in both exit situations, a relatively good performance is more likely to go public rather than sell to the acquirer. Armin [5] used the exclusion method to analyze and compare the three exit methods of equity transfer, initial public offering and bankruptcy liquidation, and constructed a survival risk analysis model to determine the risk exit method based on the exit cost and return. Chen Demian and Cai Li [6] through the analysis of the feasibility of China's current venture capital exit and the comparison of the advantages and disadvantages of venture capital exit methods, pointed out that the exit channel more suitable for China is mergers and acquisitions. Zhang Xiaolei [7] determined the best choice for IPO by means of research and analysis of venture capital related exit timing. Wang Bo [8] 
pointed out that the existing domestic venture capital exit channels mainly include backdoor listing, acquisition and merger, share repurchase, overseas second board listing, and exit through regional property rights trading market. Li Qian [9] obtained through quantitative analysis: the return rate of the VCs in the exit channel is from high to low in order of public offering, stock repurchase, acquisition, and liquidation. However, she pointed out that not all venture capitalists can choose to go public for listing and exit when venture capital exits. Wang Hankun [10] believes that the development of venture capital funds in China faces certain difficulties. It is due to the imperfect investment exit method, excessive dependence on public listing, and the over-the-counter market is underdeveloped, making many companies closeable. There are too few channels. To this end, many companies have gone public abroad, thus realizing their investment in listed financing and private equity investment funds. Liu Zhixiong [11] pointed out that due to the insufficient development of China's capital market; the exit channel for venture capital is limited. In the past, it mainly used equity transfer to achieve exit. With the launch and continuous development of the GEM market, public listing will be it will become an important way for China's venture capital to withdraw. Yanglei [12] analyzed the various factors that may be affected by the exit of venture capital from the micro and macro aspects and the empirical test. Xuxin and Xiayun [13] studied deeply the influencing factors and economic consequences of the exit of venture capital IPOs based on the description of the exit characteristics of venture capital investment of China's GEM companies from 2009 to 2013 and found that after the listing of enterprises, China's venture capital showed a feature of one-time complete exit and less discontinuation are deeply studied. Zhao Xiaohui [14] pointed that IPO exit is the exit method with the highest return on risk investment, but it should be considered in combination with the risk enterprise development plan and the market environment at the time of exit. Wang Wei [15] comparatively analyzed the advantages and disadvantages of several exit mechanisms. Shilin et al. [16] pointed that knowledge specialization and positive exit are positively correlated and knowledge specialization negative adjustment relationship embedding and successful exiting inverted U-type relationship. Chensu [17] shows that the greater the quality of the investment country and the Chinese law, the greater the possibility of successful exit of cross-border venture capital, and the higher the performance of cross-border venture capital, but this does not affect the time required for exit. And the time required for a successful exit depends more on the host country's own capital markets and technological developments.

\section{Study of Venture Capital Investment Exit Study in China}

\subsection{The Main Exit Channel Categories and Characteristics of Venture Capital}

\subsubsection{Initial Public Offering}

The initial public offering means that the venture entrepreneurs use the shares held by the invested company to conduct public listing, thereby converting the 
equity capital they hold into public equity capital, and gaining recognition through the trading market, thereby realizing capital appreciation. Before the launch of the GEM in 2009, the exit of China's venture capital institutions through listing methods was mainly listed in Shenzhen Small and Medium-sized Board, Hong Kong Growth Enterprise Market and overseas. Since the launch of the GEM, it has opened up a new way for the exit of domestic venture capital. The focus of venture capital institutions has turned to the GEM, and more and more venture capital projects have been exited through the GEM, and the exit rate of return is considerable. So this is the most important way for VCs to exit.

\subsubsection{Mergers and Acquisitions}

Corporate mergers and acquisitions mainly include mergers and acquisitions, which is an important way for companies to conduct property rights transactions. When the invested company develops to a mature stage, the invested company is integrated into a major project by the venture capital institution, and then sold to strategic investors in order to achieve capital exit, and ultimately obtain higher investment income. For various reasons, some venture companies can not obtain the listing conditions, and then withdraw, so these venture companies generally achieve the exit of venture capital through mergers and acquisitions. Although this exit method does not give investors the highest rate of return, it is a relatively flexible model.

\subsubsection{Corporate Repurchase}

Enterprise repurchase refers to the way in which the employees of the invested company and their management acquire the shares of the company that are issued, thereby achieving the exit of venture capital. This exit method is an alternative to the general venture capitalist, not a mandatory exit method. In addition, from the repurchase implementation body, the repurchase can be divided into: employee stock ownership fund (ESOT), that is, the venture capitalist purchases the shares held by the venture capitalist through the employee stock ownership fund, so that the employee will hold the risk investor. The management buyout $(\mathrm{MBO})$, that is, the management of the venture capital is used by the management of the company to recover the shares of VCs. The payment is usually made by other shares held by the management, cash from the bank, etc. The use of options to buy and sell, mainly includes stock options and stock options. However, this is also a kind of exit channel with the nature of "double-edged sword". It is to acquire its own shares from the company, and the risk investors will withdraw the capital and affect the shareholders' rights and interests.

\subsubsection{Liquidation}

Liquidation is the dissolution or bankruptcy of an enterprise due to mismanagement, etc., and then its debts and property must be cleaned up and disposed of, and venture capital must be withdrawn. There are two ways to liquidate: one is bankruptcy liquidation, that is, the enterprise cannot repay the debt when it expires, so it is declared bankrupt according to law, and the liquidation group is 
established by the court in accordance with relevant laws and regulations to liquidate the enterprise. Another way is to dissolve the liquidation. As the name suggests, it is to achieve liquidation conditions according to the company's articles of association, and then initiate the liquidation process. However, since this method is not only a very high liquidation cost, but also takes a long time, not all failed projects are cleared in this way. For a venture capital institution, once it is confirmed that the invested company has not reached the expected development speed or has no good development scenario, and thus it is impossible to obtain the expected return on investment, it will choose to immediately withdraw from the invested enterprise. The way is not only to avoid continuing losses, but also to recover funds to invest in new projects.

\subsection{China's Venture Capital Investment Accounted for Different Ways of Exit}

According to statistics, a total of 583 exit transactions were disclosed in 2016. According to the exit channel, a total of IOI projects in venture capital investment companies exited through IPO, which was generally flat compared with 2015 , but the proportion increased slightly, reaching $17.32 \%$. This is mainly the source of the capital market in 2016 is relatively stable. Relatively speaking, the M\&A transaction is still the main channel for exit, and the number of exit projects has reached 173 , accounting for $29.68 \%$. In addition, the exit rate of the project in 2016 is generally weak, and the proportion of repurchase and liquidation is higher than that of 2015 (Table 1).

\subsection{Study of Venture Capital Exit Performance}

\subsubsection{China's Venture Capital Exits Overall Performance}

As can be seen from the data in Figure 1 and Figure 2, due to the positive impact of the bull market and monetary easing in the first half of 2015, the exit performance of China's venture capital investment was as high as $260.18 \%$,

Table 1. Distribution of exit methods for venture capital investment in China (2009-2016) Unit: Percent.

\begin{tabular}{cccccc}
\hline Mear & IPO & M\&A & Repurchase & Liquidation & Others \\
\hline 009 & 25.3 & 33 & 35.3 & 6.3 & 0 \\
2010 & 29.8 & 28.63 & 32.82 & 6.87 & 1.91 \\
2011 & 29.4 & 39.97 & 32.82 & 3.17 & 5.19 \\
2012 & 29.41 & 15.86 & 45.01 & 6.65 & 3.07 \\
2013 & 24.33 & 23.75 & 44.83 & 4.6 & 2.49 \\
2014 & 20.72 & 36.02 & 36.02 & 4.83 & 2.41 \\
2015 & 15.51 & 31.02 & 37.52 & 6.5 & 9.45 \\
2016 & 17.32 & 29.68 & 40.14 & 8.06 & 4.8 \\
\hline
\end{tabular}

Data Sources: 《2016 Development Trends of Venture Capital in China》. 


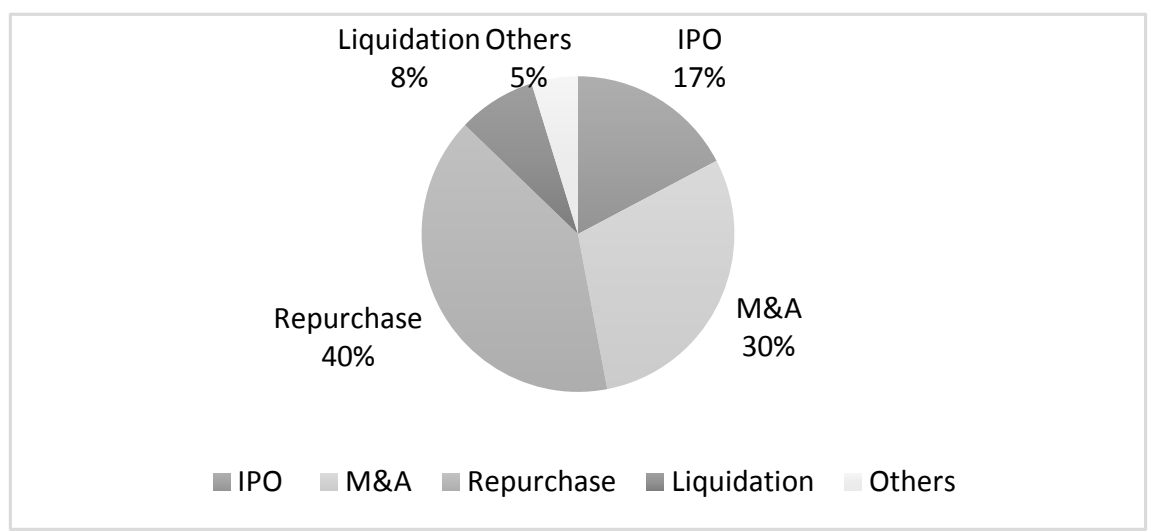

Figure 1. 2016 China venture capital exit method.

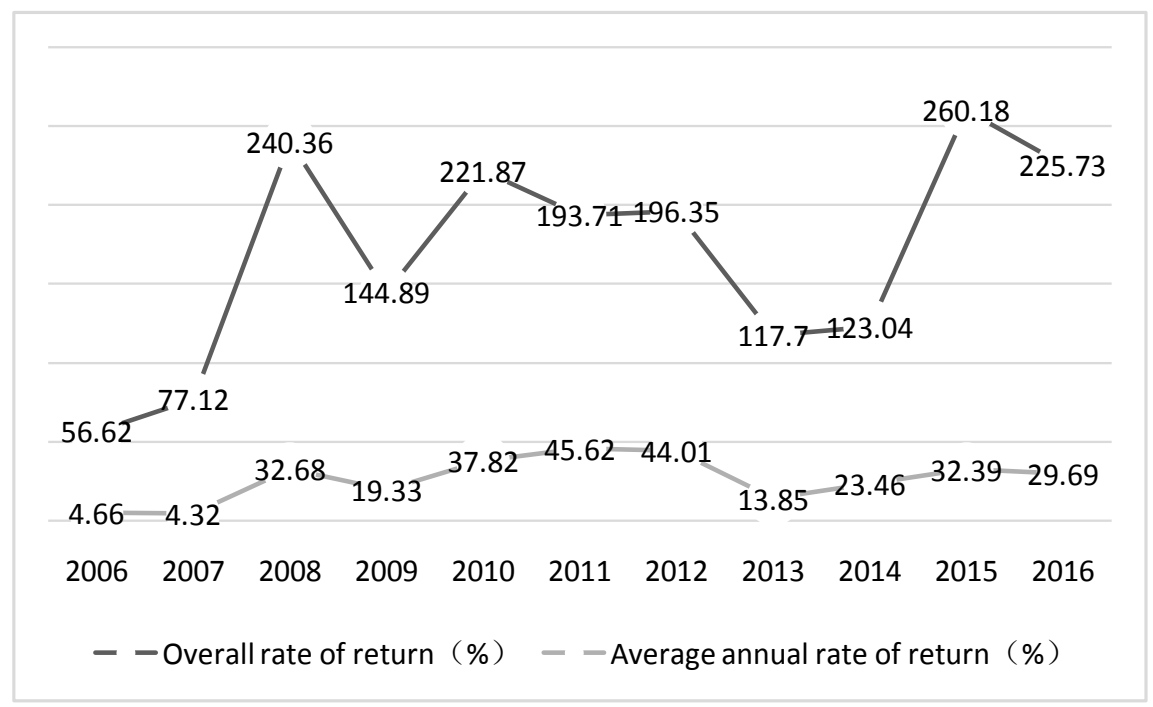

Figure 2. China Venture capital investment exit rate (2006-2016). Data Sources: 《2016 Development Trends of Venture Capital in China》.

becoming the highest point in recent years. The exit rate of the whole industry accelerated, the investment project time was shortened, the average exit time was only 3.92 years, and the overall annualized income reached $32.39 \%$. However, the exit performance of China's venture capital investment fall to $225.73 \%$ and the average exit time increased to 4.13 years.

In the specific project income, according to Table 2, although the overall income for the whole year of 2015 is more than twice, but still half of the exit projects are loss, accounting for $48.9 \%$; project income $0 \%-15 \%$ of the total. The ratio is $12.1 \%$; the proportion of income is $15 \%-20 \%$ is $3.5 \%$, the proportion of this interval is the least; the proportion of income exceeding $100 \%$ is $16.2 \%$, close to the peak of previous years.

\subsubsection{Research on the Performance of Different Exit Modes of China's Venture Capital}

Table 3 shows that the overall performance of different exit ways each year. In general, the overall performance of IPO withdrawal is the highest, with an 
Table 2. China's venture capital investment project exit rate distribution (2006-2016) Unit: percent.

\begin{tabular}{cccccc}
\hline Year & Loss & $0 \%-15 \%$ & $20 \%-50 \%$ & $50 \%-100 \%$ & $>100 \%$ \\
\hline 2006 & 73.8 & 6 & 3.6 & 2.4 & 14.2 \\
2007 & 61.2 & 9.2 & 6.1 & 8.2 & 10.2 \\
2008 & 63.2 & 3.4 & 4.1 & 8.9 & 17.1 \\
2009 & 63 & 4.8 & 10.6 & 4.2 & 14.3 \\
2010 & 63.2 & 8 & 4.7 & 4.2 & 17.9 \\
2011 & 47.9 & 9.9 & 10.6 & 6.5 & 22.1 \\
2012 & 47 & 8.6 & 10.5 & 4.5 & 25.9 \\
2013 & 67.1 & 2.4 & 8.7 & 2.2 & 16.9 \\
2014 & 56.9 & 4.7 & 9.4 & 11.6 & 13.1 \\
2015 & 48.9 & 12.1 & 11.8 & 7.4 & 16.2 \\
2016 & 56.9 & 9.7 & 9.9 & 5.8 & 15.1 \\
\hline
\end{tabular}

Data Sources: 《2016 Development Trends of Venture Capital in China》.

Table 3. Different ways to exit the project's overall rate of return (2006-2016) Unit: percent.

\begin{tabular}{cccccc}
\hline Year & IPO & M\&A & Repurchase & Liquidation & New OTC \\
\hline 2006 & 491.45 & 27.35 & -30.81 & -53.63 & - \\
2007 & 436.07 & -15.37 & -26.80 & -42.63 & - \\
2008 & 916.66 & 28.35 & -41.98 & -29.13 & - \\
2009 & 327.75 & 4.74 & -29.47 & -42.66 & - \\
2010 & 736.68 & 44.71 & -21.19 & -24.43 & 48.85 \\
2011 & 799.38 & 41.47 & -30.51 & -65.37 & 63.19 \\
2012 & 486.10 & 198.29 & 29.18 & -15.34 & 32.48 \\
2013 & 448.03 & 15.27 & -34.28 & -43.47 & 89.79 \\
2014 & 601.66 & 63.55 & -34.43 & -34.43 & 27.26 \\
2015 & 779.27 & 135.55 & 19.01 & -15.60 & 16.86 \\
2016 & 922.12 & 323.41 & 3.02 & -43.62 & 193.82 \\
Average & 631.38 & 78.85 & -18.02 & -37.30 & 67.46 \\
\hline
\end{tabular}

Data Sources: 《2016 Development Trends of Venture Capital in China》.

average value as high as $631.38 \%$, which is more than ten times that of other exit methods. The peak is $922.12 \%$ in 2016 . At the same time, mergers and acquisitions can also achieve a relatively considerable income, the average income is $78.85 \%$, but in 2007 , there was a loss, which may be because the value of mergers and acquisitions is underestimated, and full of great uncertainty; the other one is the New OTC Market, with an average value of $67.46 \%$. In the other two cas- 
es-repurchase and liquidations-they can only exit with a loss. But in order to avoid big losses, VC typically put buyback clauses into their investments.

From the perspective of the whole year of 2015, the performance of all kinds of exit methods is higher than that of previous years, among which the return rate of IPO is as high as $779.27 \%$, nearly eight times. The return rate of merger and acquisition methods has doubled from $63.55 \%$ in 2014 to $135.55 \%$ in 2015. The performance of repurchase also changed from a loss of $34.43 \%$ in 2014 to a profit of $19.01 \%$, while the loss of liquidation also decreased by nearly half. However, the yield from the New OTC Market has declined. In general, VC benefited from the capital market situation in the first half of 2015.

From Table 4, we can conclude that the overall market volatility from 2015 to 2016 was optimistic. Except for liquidation, the average annual return from other methods was positive, but the annual average income gap between IPO and other methods still exists. Despite the high return on IPOs, the 2015 revenues only reached historical averages; in addition, the proceeds from M\&A were particularly eye-catching, with a significant year-on-year increase, from $17.49 \%$ in 2014 to $44.45 \%$ in 2015 , significantly greater than the average in previous years. The yields of repurchase and liquidation have also improved from previous years, and the repurchase has also changed from a loss in 2014 to a profit of $4.05 \%$ in 2015.

Generally, it takes 4 - 7 years for a project to exit from investment. Therefore, from the perspective of average annual return rate, venture capital industry is not an industry that gets rich overnight. Seen from the past years, the average annual return of IPO withdrawal is the highest. The average annual return in the past decade is $112.4 \%$, and the peak is $200.41 \%$ in 2010 , which has reached twice. The second is merger and acquisition. The average annualized income in the past decade is $17.57 \%$, and the highest is $66.4 \%$ in 2012 . However, there was a loss in 2007. Then, the average annual income withdrew from the New OTC Market, is $10.91 \%$. The average annual return on repurchases and liquidations over the past decade remains a loss, at $-8.01 \%$ and $-8.55 \%$, respectively.

\section{Conclusions}

This paper sorts out the data of China's venture capital investment exit projects in the past ten years. Through the average, it is found that in the exit mode, the proportion of repurchase and mergers and acquisitions is relatively high, accounting for $37.68 \%$ and $28.32 \%$ respectively, followed by IPO. It is $24.92 \%$. This is because IPOs are difficult, time consuming, and costly, and it is difficult for companies with venture capital to grow to this stage. In the IPO project, most companies choose to list in China, and only $6.8 \%$ choose to list overseas. Most of the projects listed in China are listed on the GEM, accounting for $36.12 \%$.

In terms of exit performance, the project can achieve good returns from the overall perspective of the venture capital project, but this is the average result. In the early years, the mutual damage project reached $60 \%-70 \%$, which has been 
Table 4. Average annual rate of return for different exit methods (2006-2016) Unit: percent.

\begin{tabular}{cccccc}
\hline Year & IPO & M\&A & Repurchase & Liquidation & New OTC \\
\hline 2006 & 45.55 & 15.00 & -14.28 & -17.57 & - \\
2007 & 46.53 & -9.35 & -4.94 & -7.86 & - \\
2008 & 143.33 & 1.33 & -17.61 & -6.05 & - \\
2009 & 113.08 & -0.37 & -21.01 & -6.59 & - \\
2010 & 187.62 & 5.04 & -5.35 & -4.83 & 5.64 \\
2011 & 200.41 & 12.99 & -20.71 & -8.46 & 13.20 \\
2012 & 84.62 & 66.40 & 14.86 & -10.33 & -4.47 \\
2013 & 73.36 & 2.71 & -19.31 & -8.26 & -0.90 \\
2014 & 107.19 & 17.49 & -4.22 & -11.48 & 12.93 \\
2015 & 114.38 & 44.45 & 4.05 & -2.00 & 6.10 \\
2016 & 120.35 & 37.58 & 0.38 & -10.66 & 43.89 \\
Average & 112.40 & 17.57 & -8.01 & -8.55 & 10.91 \\
\hline
\end{tabular}

Data Sources: 《2016 Development Trends of Venture Capital in China》.

alleviated in recent years. The rate is about half, which means that the risk of VC is very high.

From the comparison of different exit methods, the return rate of IPO is the highest, both in terms of overall return rate and average annual return rate, far exceeding the return rate of other exit methods, especially in the bull market in the first half of 2015, the overall return. The rate is $779.27 \%$, and the return rate in the year is as high as $114.38 \%$. There is a great uncertainty in the exit of the M\&A method, and it is still profitable overall.

\section{Conflicts of Interest}

The author declares no conflicts of interest regarding the publication of this paper.

\section{References}

[1] Ren, H.D. (2000) Research on China's Venture Capital Exit Mechanism. Financial Research, 2, 29-33.

[2] Zheng, K. and Zheng, X.Q. (2003) Comparison of Risk Investment Exit Channels and the Practical Ways That China Can Adopt. Finance and Trade Economy, No. 6, 90-92.

[3] Brau, J.C., Francis, B. and Kohers, N. (2003) The Choice of IPO versus Take Over. Empirical Evidence, No. 4, 178-201

[4] Nahata, R. (2004) Venture Capital Reputation and Investment Performance. Journal of Financial Economics, 90, 127-151

[5] Schwinenbacher, A. (2005) Innovation and Venture Capital Exits. University of Amsterdam, Amsterdam, 35. 
[6] Chen, D.M. and Cai, L. (2003) Risk Investment Operation Mechanism and Management. Economic Science Press, Beijing.

[7] Zhang, X.L. (2006) Exit Mechanism and Modeling Analysis of Venture Capital. Industrial Technology and Economy, No. 2, 144-145

[8] Wang, B. (2008) The Choice of China's Venture Capital Exit Method. Finance and Economy, No. 2, 46-48

[9] Li, Q. (2008) The Timing and Method of Exiting Venture Capital. Discussion on Modern Economy, No. 3, 69-72

[10] Liu, Z.X. (2010) Analysis and Comparison of China's Venture Capital Exit Mechanism. Science, Social Economy, No. 2, 55-60

[11] Wang, H.K. (2009) Research on the Exit Mechanism of Private Equity Investment Funds in China. Tianjin University of Finance and Economics, Tianjin.

[12] Yang, L. (2010) An Empirical Study on the Factors Affecting the Exit of Venture Capital in China. Nanjing University of Finance and Economics, Nanjing.

[13] Xu, X. and Xia, W. (2015) Risk Investment Characteristics, Risk Investment IPO Exit and Enterprise Performance-An Empirical Study Based on China's Growth Enterprise Market Listed Companies. Economic Management, No. 5, 97-107.

[14] Zhao, X.H. (2016) Research on the Choice of Exit Methods for Venture Capital in China. Jinan University, Guangzhou.

[15] Wang, W. (2016) Reflections on the Exit Mechanism of Venture Capital in China. Modern Business, No. 3, 99-100

[16] Shi, L., Dang, X.H. and Han, W. (2017) The Impact of Risk Investment Institutional Intercalation and Knowledge Specialization on Successful Exit: An Interaction Effect. Finance and Trade Research, 11, 79-87.

[17] Chen, S. (2017) The Impact of Institutional Distance on Cross-Border Venture Capital Performance-An Empirical Test Based on Chinese Market. Studies in Financial and Economic Issues, No. 7, 36-44. 